\title{
1. Knowledge for peace: transitional justice and the politics of knowledge in theory and practice
}

Briony Jones and Ulrike Lühe

\section{INTRODUCTION}

The search for justice following large-scale violations of human rights is like a double-bind ${ }^{1}$ in which competing yet equally valid messages challenge researchers, policy-makers and practitioners alike. While respecting universal human rights we must remain attentive to context; while drawing on available expertise we must avoid marginalizing other voices; and while seeking order and peace we must show willingness to see and understand disruption and conflict. Because of these creative, normative, epistemic and political tensions we are often challenged to name, describe and categorize experiences, people and places in ways that are too static to fully capture the dynamics of transitioning from violence to peace. But we continue to try and do so, by seeking better categories, better methods and better working ethics. The field of transitional justice is characterized by substantial and difficult debates over what 'better' looks like, and we offer our contribution to these debates with this book on the politics of knowledge.

The politics of knowledge is particularly pertinent for a field which, like other peacebuilding endeavours, has the explicit aim of generating knowledge which informs and improves action. Nonetheless, while there are many critical scholars of peacebuilding and transitional justice who seek to deconstruct dominant narratives and challenge assumptions, they also engage and operate in a field which has normative aims. We all want more justice, more peace and more freedom. The debate is over how to get there and indeed how we know what arrival looks like. The end points of justice and peace are not an objective and static point we can see far off in the distance as we edge towards them. Rather, the journey itself changes the destination. In the process of researching, talking about, trying to establish, and measuring and assessing, we determine what it is we are seeking. 'Justice', 'reconciliation', 'truth' and 
many other of the field's key concepts and concerns emerge from our debates and conflicts, a product of the varied and perhaps competing ways in which we approach transitional justice as an object of knowledge.

In this book we present a series of chapters which tackle the question of the politics of knowledge and how it relates to and plays out in the field of transitional justice. The mix of theoretical and empirical chapters is relevant not only for scholars of transitional justice but also for those of peace(building), international intervention and the sociology of knowledge more broadly. As will be elaborated in this introductory chapter we make our contribution by drawing on previous scholarship on the politics of transitional justice and its knowledge landscape. We also go beyond this scholarship by focusing for the first time on what knowledge is valued and foregrounded, which agendas shape the scholarship and practice of transitional justice, and the profound consequences this has on policy and practice. While other work has engaged with this topic through other lenses, for example with a focus on norms and norm diffusion or actor-focused analyses of advocacy networks, this book is the first one to focus specifically on the politics of knowledge (production) as the conceptual entry point and to discuss in depth the research-policy-practice nexus. As we will elaborate further below, the field of transitional justice was established through exchanges between these different epistemic communities of research, policy and practice, and any discussion of the politics of knowledge requires a discussion of the actors, communities and knowledge-producing practices which determine what we know and how it is known. This introductory chapter fleshes out the key contours of the book and its collection of chapters. First, we provide an overview of the key debates to which this book speaks and the red threads which run throughout the chapters and to which we asked authors to make contributions: (1) the interlinkages between the processes and politics of knowledge production; and (2) the research-policy-practice nexus. Second, we summarize the content of the chapters and describe how they connect and complement each other in their analyses.

\section{KNOWLEDGE OF, FOR AND BY TRANSITIONAL JUSTICE}

The field that is termed 'transitional justice' is an assemblage of ideas, actors, actions and objects. On the one hand, there is the idea of transitional justice which comprises both a set of aspirations and dominant norms. On the other hand, there is the practice of transitional justice which is made up of varied interventions, mechanisms and processes which may be more or less in line with the dominant norms. In turn, transitional justice has 'three main objects: the situations it examines, the mechanisms applied to them and its self-referential engagement with transitional justice' (Zunino, 2019: 22). As 
a field it is developed out of, and in reference to, practices that bring about a plethora of 'experts' and a dynamic relationship between research, policy and practice. This all leads to a rich and complex knowledge landscape, infused with a politics of whose knowledge counts, whose knowledge is acted upon, and what is even considered to be knowledge. This includes knowledge produced outside of transitional justice for use by its actors, knowledge produced on transitional justice and its ways of working and imagining, as well as the knowledge produced within and through transitional justice discourse and practice. In order to articulate the particular contribution of this edited book to understanding the politics of knowledge and transitional justice, it is important to outline the scholarship that has enriched the discussion thus far and to which the authors owe an intellectual debt of gratitude. We have divided the work to which this book speaks into four key debates: (1) the emergence of the transitional justice norm; (2) knowledge imperialism; (3) identifying the 'local'; and (4) the research-policy-practice nexus.

\section{The Emergence and Diffusion of the Transitional Justice Norm}

Transitional justice endeavours are underpinned by a normative agenda which seeks a certain kind of justice assuming that this will lead to peace as it will 'pacify volatile regions' (Anders and Zenker, 2014: 398). This justice seeking has been inextricably linked to liberal democracy. The contemporary field of transitional justice developed primarily in response to the political transitions of South America and Eastern Europe during the 1970s, 1980s and 1990s (Arthur, 2009). The bringing together of human rights frameworks with literature on democratic transition by the transitional justice field 'made the question of justice central to democratic transitions, but also made the question of political transformation central to the idea of justice' (Hansen, 2014: 109). While transitional justice has expanded and now includes transitions in societies negotiating settlements in protracted social conflicts (Bell, 2009: 8 ), transitional justice is still inherently concerned with the transformation of political communities, a transformation which is seen to be one towards a liberal democracy (Sriram, 2009).

This has been much debated in the transitional justice literature and the idea of a paradigmatic transition has been described as having three components: first, that the previous regime is understood to be illegitimate; second, that the changes brought about by the transition are generally relatively uniform throughout the state; and, third, that it is a process of closure (Ní Aoláin and Campbell, 2005: 173, 181-2). The challenge in early paradigmatic cases like Argentina was to identify the appropriate legal tool to address past human rights violations without threatening the transition towards democracy (Murphy, 2017: 29) and, importantly, a transition to liberal democracy under- 
stood in relatively procedural terms (Ní Aoláin and Campbell, 2005: 176). As Andrieu points out, '[b]ecause peacebuilding and transitional justice still rest on a high-politics vision of the state, both focus more on the consolidation of democratic institutions than on the nurturing of democratic politics' (2010: 545). This is seen by such authors as the result of the liberal democracy norms which inform the field, and the way in which it has been consolidated as a norm born of Western Enlightenment traditions of thought (see below).

Sharp has recently written of the 'dominant script' of transitional justice as the 'liberal-legalist' paradigm which determines what is emphasized and what is marginalized (Sharp, 2018: ix). This has been a potent rallying cry for activists, non-governmental organizations (NGOs) and international organizations in acknowledging and addressing large-scale violations of human rights, but it has also led to a narrow focus as the international norm of transitional justice has emerged, evolved and crystallized (Rubli, 2012). Transitional justice as a field of policy and practice has directed its efforts towards certain types of (physical) political and civil violence, has a tendency to implement processes through a top-down template-driven tool-box approach, and has been accused of drawing too heavily on Western and liberal modalities of justice (Sharp, 2018: ix-x). Structural forms of violence, non-state-led forms of change and non-liberal modalities of justice, often referred to as 'traditional justice', have therefore been relegated to the background or even considered to be a threat to transitional justice. This has all been captured in what Nagy (2008) has referred to as the 'global project' of transitional justice. This global project describes a global transitional justice norm through which transitional justice has become an inevitable response in transitioning societies and those that have a past to account for. As Nagy writes: 'The question today is not whether something should be done after atrocity but how it should be done. And a professional body of international donors, practitioners and researchers assists or directs in figuring this out and implementing it' (ibid: 276).

The establishment of the global norm of transitional justice, partly captured in the UN Principles to Combat Impunity ${ }^{2}$ and the work of the Special Rapporteur on the Promotion of Truth, Justice, Reparation and Guarantees of Non-Recurrence, ${ }^{3}$ and partly captured by the plethora of expectations and activities around transitional justice interventions (Rubli, 2012), has profound effects on the way we think about and do transitional justice. The origins of the field inextricably link justice with liberal democracy, thereby conditioning what counts as transitional justice, and therefore what counts as knowledge about and for transitional justice. As we will see in the following sections the emergence of the global norm of transitional justice also shapes how knowledge is mapped onto power relations and vice versa, particularly those between the Global North and the Global South, how critical scholars have attempted to capture marginalized voices, and how epistemic communities of research, 
policy and practice interact. In this way, the norm of transitional justice establishes a politics of knowledge relevant for all of the chapters in this book.

\section{Knowledge Imperialism}

Kagoro contends that the particular origins and development of the transitional justice norm, as discussed above, are part of a 'post-cold war ascendency of particular, culturally laden narratives about history, society, governmentality and justice' (2012: 10). He goes on to write of transitional justice's 'knowledge imperialism' (ibid: 12) - a term that reflects the substantial debate in the transitional justice literature about the extent to which the 'dominant script' of transitional justice (Sharp, 2018: ix) continues the imbalances and even violence of relations between the Global North and the Global South. Indeed, the production of knowledge on and for transitional justice is not a practice that different actors can engage in equally: 'only a particular set of people, in a particular set of circumstances, is able to shape the research agenda which in turn informs policies that shape the world' (Nouwen, 2014: 258). The scholarship puts forward that this set of people are primarily internationally mobile and privileged 'experts' educated in the language of the global norm described above. To illustrate this inequality Nouwen offers the following observation:

Take, for example, the authority of former Principal Judge in Uganda, Justice James Ogoola. Patiently and poetically, he has answered the questions of many a researcher regarding the Ugandan International Crimes Division (ICD, also known as UWCC), for which he laid the foundations. He is the authority on the topic. But when his speech on the ICD was published in a US law journal, the editors complemented it with footnotes. (Ibid.)

Numerous such anecdotal examples abound in the field of transitional justice research, of projects with 'local' partners relegated to mere data collectors while academics based in the Global North advance their careers by extracting such knowledge and translating it for consumption.

However, while such problematic dynamics of extraction and unequal relations certainly exist and are an ethical problem for the field, it is not a simple case of the 'Global North' versus the 'Global South' as a closer look at the origins of some of the field's most dominant ideas reveals. First, the Western triumphalist narrative hides the fact that international law and the assumption of its universality were developed as a consequence of colonialist thinking and practice and thus in the interaction between the Global North and the Global South. The emergence of transitional justice as part of the liberal peacebuilding infrastructure (Sriram, 2009) and as an international bureaucracy firmly situated in the Global North (Rubli, 2012) has meant that it has been led and promoted by Western liberal democratic countries that were colonizers 
(Yusuf, 2018) and which continue to operate in a global order that supports and maintains their influential status. Second, positing that transitional justice originated in the Nuremberg Trials also frames it as 'entirely a postcolonial enterprise' (Maddison and Shepherd, 2014: 261):

The exceptionalism that defines the context of transitional justice is in itself a colonial practice of power. The imagined history of transitional justice that locates its inception at the Nuremberg Trials effectively posits that transitional justice mechanisms [were] literally brought forth into existence by the horror of the Holocaust. This discursive move allows the 'international community' to reset the standard of justice and, by association, delineate a new boundary around crimes that were so severe as to require new ways of dealing with them. These crimes were considered exceptional, and thus in need of new mechanisms and new conceptual frameworks. Except such crimes were not exceptional. Such crimes were part of the everyday lexicon of colonial power. Empires such as those founded by the same powers that organized post-World War II to ensure that Nazi war criminals were brought to justice, were founded on violence, often genocidal violence [...]. (Ibid: 262)

The exceptionalism that is associated with transitional justice thus helps to marginalize not only the un-exceptional character of many human rights violations for large parts of the world, but also the very knowledge of these crimes, and the ways of knowing associated with non-Western attempts of making sense of these.

Third, many of the key cases and practices which have established the field as such are non-Western. The 'original' cases of Latin America in the 1970s and 1980s are foundational, as are many of the oft-cited African cases - Rwanda, South Africa, Uganda, Kenya - in shaping how the contemporary field of transitional justice operates. Fourth, most of the current research and knowledge produced in the field emerges from the interaction of researchers and practitioners, often placed in the Global North and the Global South, and is the result of (often unacknowledged) interactions and relationships. Declaring this knowledge international, while true in some sense, thus also helps to hide the contribution of Southern stakeholders.

However, the knowledge imperialism referred to by Kagoro (2012) is now also being challenged explicitly by initiatives such as the African Union Transitional Justice Policy (AU, 2019) or the African Commission on Human and Peoples' Rights' (2019) recent report on transitional justice in Africa. The latter identifies African specific innovations which have contributed to expanding the mainstream approach to transitional justice:

1) taking local conceptions of justice into account, especially in terms of collective versus individual approaches to justice and reconciliation; 2) going beyond the mainstream focus on civil and political rights violations to address economic, social and cultural rights violations, historical and structural inequalities, and issues of 
sustainable development; and 3) acknowledging the differential impact of conflict on women and the need for women's participation in the design and implementation of TJ. (Ibid.: vi)

These innovations are attributed to continental policy-making around the African Charter and the Malabo Protocol, ${ }^{4}$ demonstrating sustained African engagement with transitional justice which does not take the established global norm(s) for granted. This is particularly relevant for the debate around 'local' forms of transitional justice and 'local' forms of knowledge which follows in the next section.

The dynamics outlined here indicate not only that knowledge cannot be assumed to simply be produced in the Global North and transferred to and applied in the Global South. Instead, the critical transitional justice literature is starting to hint at a more complex, interdependent and interactional relationship between the Global North and the Global South in which knowledge is co-produced through cooperation and resistance and challenged by both scholarship and policy-making. This complex relationship, however, often remains invisible. Furthermore, the outlined dynamics also point us towards the third theme of this book, the (overlooked) complexity of the 'local'.

\section{Identifying the 'Local'}

In the transitional justice literature the possibilities and limitations of local ownership have been discussed at length. ${ }^{5}$ Local ownership as a lens of critique emerged largely in response to the standardized solutions that are offered by international actors from the Global North to the Global South, which are seen as undermining local ownership in terms of control, process and substance (Sharp, 2013). While the one side of the argument focuses on the dominance of actors from the Global North in designing, implementing and evaluating transitional justice practice and producing transitional justice knowledge, the other side focuses on uncovering the Eurocentrism inherent in the field (as discussed above).

The 'local' turn in transitional justice thus includes ideas such as 'justice from below' (McEvoy and McGregor, 2008), the taking into account of different positionalities and standpoints in a 'localized' transitional justice (Shaw and Waldorf, 2010), contesting foreign knowledge in a search for an African transitional justice (Bennett et al., 2012), or struggles over who owns and shapes a particular transitional justice process (Thomson and Nagy, 2011, on the case of Rwanda). Contesting dominant knowledge/s has been an important part of the evolution of the field of transitional justice, and discussions about what a local transitional justice is, and what it adds, as well as how it can be captured, are important foundations for the work of this book. However, an 
assumption persists of an unequal binary between international 'experts' and local 'knowledge' with the latter having instrumental value to the experts as they make policy decisions. Therefore, any attempt to reclaim, revive or render visible the 'local' in transitional justice may still be read as an act of those with epistemic privilege seeking to give back power to those whose voices have been marginalized. Thus, instead of deconstructing which voices are seen to be expert and which are seen to be local in the first place these critiques invariably assume and perpetuate a problematic 'sense of naturalness and inevitability' of transitional justice (Sharp, 2018: 14, emphasis in original) and (the positionality of) its actors.

Indeed, according to Colvin the problem for transitional justice vis-à-vis the local context is not one of a lack of knowledge, but rather a 'failed ethical relationship to the other' (2008: 424). Colvin's observation demands a reflection on how the politics of knowledge of transitional justice produces certain types of relationships between those who claim knowledge and those to whom the knowledge refers. This includes any designation of an actor, knowledge or space as 'local' for this belies a series of assumptions about the role that can be played by anyone designated as 'local' and how that which is 'local' can be known. In reality the merging, intersections and overlaps between what is named 'international' or 'local' are more illuminating than any such categorizations. Attempts to obfuscate the grey areas and complexities may end up serving the interests of those with epistemic privilege who seek to 'discover' the local without fundamentally changing the relationships of power which determine the politics of knowledge.

\section{The Research-Policy-Practice Nexus}

The establishment, strengthening and global diffusion of the norm of transitional justice outlined above have gone hand in hand with the field's bureaucratization and professionalization and a burgeoning of think tanks, consultants and university courses (Rubli, 2012). Hansen has described this as the 'vertical expansion' of the field meaning that 'actors both above and below the State level are increasingly perceived as being relevant for shaping and implementing transitional justice solutions' (Hansen, 2014: 105). In the process, experts have moved from truth commissions to international organizations, from academia into tribunals, and so forth. Lawyers in particular have moved freely between institutions and 'taken leadership roles in the international tribunals whose creation they have advocated for' (Vinjamuri and Snyder, 2004: 348). This has continued to blur the lines between research, policy and practice in a field which anyway has its origins in an impulse to act to seek redress for violations of the past and ensure a political transition to democracy. Miller 
(2008: 271) has observed the importance of this character of the field for how to think about a politics of knowledge, noting that:

Transitional justice operates through the actions of a series of groups: policy makers $[\ldots]$ victims groups $[\ldots]$ the larger citizenry $[\ldots]$ scholars $[\ldots]$ and practitioners $[\ldots]$ the movement of ideas about and modes for transition bespeaks not only a series of 'lessons learned' but also potentially the transfer of ideological preoccupations that underpin the seemingly neutral discourse of the project.

Miller goes on to identify an important 'tendency of scholars or ex-commissioners to become consultants to, rather than fully external critics of, the enterprise' (2008: 290). Descriptions of the kind of knowledge which is elevated in these contexts include 'technical', 'professionalized' and 'mobile' expertise (Nesiah, 2016: 34, cited in McAuliffe, 2017: 180) which reinforces the dynamics identified in the previous sections - a dominance of Global North, presumed universally applicable knowledge which 'favours models that are already legible to the field and its "best practices", rather than innovations that may extend or challenge the field as we know it' (ibid.).

The way in which the epistemic communities share knowledge, contest knowledge or reinforce models and assumptions is vital for understanding what is even considered to be possible in terms of an individual intervention or transitional justice process. Despite this, the research-policy-practice nexus in transitional justice is insufficiently well-understood and has not been the focus of sustained analysis and discussion. The critiques outlined in the previous sections thus form the starting points of the intellectual preoccupations of the chapters in this book - work which seeks to break down the many binaries that dominate transitional justice thinking, to take a step back to look at what even counts as knowledge, and to reflect on how we can capitalize on the research-policy-practice nexus.

\section{QUESTIONS AND CONTRIBUTIONS OF THE BOOK}

With this background in mind the project from which this book has emerged had a series of aims: to analyse the discursive and material practices of transitional justice; to explore how knowledge about 'peace' and 'justice' is produced and the politics of these processes, including research-policy-practice exchanges; and an analysis of what this means for which types of policies are enacted and which policy options might be overlooked or marginalized. ${ }^{6}$ While some very valuable work has been done on the politics of knowledge in peacebuilding scholarship, as well as on how the politics and power of transitional justice marginalize certain voices while elevating others, there has yet to be published a book such as this which brings these insights together and which focuses spe- 
cifically on what the politics of knowledge means for (1) how we imagine what is possible in policy and practice and (2) research-policy-practice synergies.

The contributions in this book thus go beyond existing studies which focus on how to translate complex realities to policy actors (see for example Carden, 2009; Paris, 2011), on how research feeds into development practice and can be used by development practitioners (Verkoren, 2008; Laws et al., 2013), on how researchers can justify programmes or convince donors (Davies et al., 2005; Bush and Duggan, 2014), or even the taken-for-granted assumption about the importance of the relationship between research, policy and practice. Instead, the contributions presented here start from the assumption that before we decide which knowledge should be acted on, we need to know more about what counts as knowledge. This is what we mean when we refer in this book to the 'politics of knowledge'. The work of the project, and the ideas expressed in the chapters of this book, thus speak to questions of how knowledge is generated, how the boundaries of such knowledge come to be determined, which forms of knowledge are considered to be more legitimate and authoritative, and how, thus, the politics of knowledge production shapes the types of policies which are considered, designed and implemented. The contributions are guided by two themes:

1. The interlinkages between the processes and politics of knowledge production: What are the assumptions, cases, practices, exchanges which form the starting point of knowledge and shape how it is produced? What types of knowledge are being produced? How do the processes of knowledge production interact with (the) politics (of knowledge)? Who is considered an expert? How is expertise constructed?

2. The research-policy-practice nexus: How do these communities exchange, engage and interact? Does the distinction between these groups indeed provide a useful lens for understanding knowledge production (in theory and practice)? Does 'research' in this nexus grasp the processes of knowledge production identifiable in the field of transitional justice? If not, what does this mean for the research-policy-practice nexus?

Each chapter speaks to one or both of these two themes and draws on both conceptual and empirical insights. The authors draw on different disciplinary backgrounds, their belonging to different epistemic communities, and their own first-hand experience. While the fact that the book is edited by scholars based in the Global North is not to be ignored, the book is also important in the way it brings together authors from the Global North and Global South in reflective accounts of how we write about the politics of knowledge and are ourselves part of that politics. With that in mind, in the section which follows we map the content of the chapters in relation to the overall themes of the book. 


\section{MAPPING AND CONNECTING THE CHAPTERS ${ }^{7}$}

Part I on the Politics of Knowledge for Peace comprises three chapters which provide a theoretical context for the empirical chapters in Parts II and III of the book. We open with the chapter by Halistoprak in which he traces the interplay between theory and practice in International Relations and Peace Studies. Charting over time the role of different knowledge in the claims made by scholars in these fields, Halistoprak shows us that 'discussing knowledge production becomes a debate less about the merits of certain methodological approaches and more a question of how the political context in which knowledge production takes place shapes the process itself'. In his chapter we see clearly the importance of the interactions between research and practice in shaping the knowledge landscape of Peace Studies, and how 'the practice of peace relies on a certain understanding of peace constructed not only through practice but also through theory'. Theory and practice cannot, and should not, be separated in considerations of the politics of knowledge for peace. This theme is continued in the chapter by Goetschel in which he charts the concrete points of interaction between research and policy, namely the turn towards evidence-based policy-making, promotion of pragmatic approaches to peace practice, and research partnerships. In doing so Goetschel urges us to take on board that debates over the nature of peace 'are not just about the adequacy of technical approaches and solutions but also about political preferences'. He argues that although the field of peacebuilding has evolved into an evidence-based, policy-facing field 'the science-policy interaction remains largely opaque and power sensitive'. Goetschel presents a way forward by incorporating a consideration of power through substantive conflict sensitivity assessments alongside well-managed research partnerships. He argues that these practices equal a 'political sensitivity' check or a socio-political positionality assessment - something that is ultimately required if peace research is to have the impact expected and desired by all actors in the field.

In the final chapter of Part I, Jones, Lühe, Fokou, Logo, Moro and N'Da connect the politics of knowledge themes identified by Halistoprak and Goetschel with the specifics of the empirical project from which this book has emerged. More specifically, as a project team we reflect on a conversation from the final project workshop in which we discussed the experience of working in a Global North-South research partnership. While current practice and requirements from funders require that such partnerships are central to projects, this chapter unpicks the realities of one such partnership and poses difficult yet important questions. Identifying 'the multiplicities and tensions inherent in layers of positionality that we inhabit and the emotional and ethical implications of our work and conduct as research partners' the chapter 
identifies key factors driving, shaping and complicating relations between the team. Looking closely at how positionality, ethics and emotion featured in the team dynamics, this self-reflexive piece "works its way through the idea of the "research partnership", not as an ideal or as it is planned on paper and in project management scenarios, but as it plays out in the realities of project implementation'. This chapter attempts to be open about the vulnerabilities, aspirations, experiences and contradictions, which are clearly important for shaping how research partnerships play out in practice, but which do not feature in funder checklists or project management frameworks.

Moving on to Part II the book turns towards The Interlinked Politics of Knowledge Production and Agenda Setting with chapters on the cases of Côte d'Ivoire, Burundi and Zimbabwe. In the first chapter N'Da and Fokou describe and analyse the 'peace market' in post-2011 Côte d'Ivoire and attempt to establish and, in so doing, to define social cohesion. In the rush of actors and funding entering the country there has been a 'lack of a common framework of reference between the various transitional justice actors' which, when combined with the resource asymmetries that shape many transitional justice contexts, has led to 'high levels of field deployment by international actors who implement activities based on their frameworks of reference, experiences and practices learned from other contexts'. This international-local tension and dynamic has led to the legitimization of knowledge produced outside of Côte d'Ivoire, and the 'knowledge and know-how, the theoretical skills and the experience held by these actors external to Côte d'Ivoire have structured the dependency/interdependence relationship between stakeholders'. N'Da and Fokou link this politics of knowledge to the lack of progress on a unifying national social cohesion policy which is struggling to have impact on the daily lives of Ivoirians. They point towards consultation over different versions of transitional justice, greater coordination between actors working on social cohesion, and political will to engage with the challenge of social cohesion as a social process, as factors which could lead to change. Ultimately, the competitive arena over who can determine conceptualizations of, and policies for, social cohesion is leading to ongoing harm for the Ivoirian population.

Chapter 6 by Lambourne also takes as an entry point the competition between different actors to determine the transitional justice agenda, this time in Burundi. Lambourne describes what she sees as the 'political struggle for control over the production and dissemination of knowledge' which has characterized the transitional justice experience of Burundi. This struggle has taken place between different levels - international, national and local - as well as between different actors - policy-makers, practitioners, funding agencies, civil society advocates and research scholars. Importantly, she argues it has 'had a profound influence on the mechanisms and programs that have been pursued and the impact these have had'. Focusing on the trajectory laid out by 
the Arusha Peace Agreement and the Truth and Reconciliation Commission, this chapter focuses on the tension between the United Nations and the Government of Burundi as they try to influence the discourse and, ultimately, practice of transitional justice. Looking at these struggles through the lens of the politics of knowledge production, Lambourne is able to highlight the role that attempts to control knowledge play in how transitional justice processes may falter. She thus argues for 'a more explicit accounting for the influence of knowledge producers on the process and outcomes of transitional justice'.

In the final chapter of Part II, Njeru and Masiya undertake a detailed critique of the 'Taking Transitional Justice to the People Programme' of the Zimbabwe Human Rights NGO Forum. They frame their analysis with reference to debates over Global South marginalization in knowledge production on transitional justice, as well as the elevation of theoretical knowledge above grassroots/activist/practitioner knowledge which 'undermines the possibilities of dialogue between grassroots activists and the scholarly community'. Charting this specific programme from its conception through to activities and its impact, Njeru and Masiya call into question the use of models imported from other contexts or replicated from the international norm of transitional justice, the way in which translation between language and cultures has not been taken into account, and methods of imparting knowledge to the people of Zimbabwe and thus assuming their ignorance or at least inability to engage more actively. In doing so they also point out that the Forum is part of larger structures and systems which reproduce hegemonies of knowledge, highlighting how we cannot analyse any given transitional justice intervention as stand-alone or disconnected from the field's broader power dynamics in terms of the politics of knowledge.

Part III of the book is focused on Knowledge Producers: Experts and Expertise with four chapters on the cases of commissioners of truth commissions, the experts involved in developing the African Union Transitional Justice Policy, the role of the Intergovernmental Authority on Development in South Sudan, and the communicative acts of the population, domestic elites, diasporas, international actors and documentary makers in Burundi. These chapters focus on actors and notions of expertise as the entry point to the politics of knowledge. The first chapter by Wouters explores whether there is a common framework governing the selection of commission members by looking at the truth commissions of Argentina, El Salvador, Chile and South Africa. Wouters argues that truth commissions seek to establish representativity and objectivity as an institution, among others through the selection of their commissioners. However, individual subjectivity of commission members will always exist. As a consequence, the only way to increase objectivity is through overall commission composition. Differences in commission compositions are due to 'differing ideals of objectivity', leading to the finding that authority, 
skills and representation are all relevant factors that make commissioners suitable for their delicate work. This context-specific definition of expertise contrasts with the objectivity claims which are made around the selection of commissioners, claims designed to confer authority on the truth commission and its work and thus credibility on its findings and recommendations.

In the chapter which follows, Lühe focuses on the development of the African Union Transitional Justice Policy and investigates how expertise was assembled in the making of the policy. She points out that little attention has been paid in the transitional justice literature to Southern practices of producing knowledge and assembling expertise for policy-making and that academic debates often focus on technical knowledge as the basis of expertise and a shaping factor in policy-making. It thereby limits our understanding of how transitional justice is rendered knowable in specific contexts and how experts meet the shifting demands for expertise in a given policy process. Lühe analyses two key consultation practices - policy revisions and consultation meetings - to illuminate the way in which expertise emerges from the process and how it is assembled and folded into the policy process over time. Her findings however go beyond this particular policy process to be relevant for assembling expertise in the transitional justice field more generally and in other policy processes, demonstrating its necessarily assembled, contested and exclusive character.

In the next chapter Logo reflects on the role of context, in particular that of the non-transition context of South Sudan, and how the politics of knowledge around establishing the Hybrid Court for South Sudan plays out between key actors. She focuses her analysis on the Intergovernmental Authority on Development (IGAD) and the role of regional politics in determining who is able to shape the agenda and control the circulation of information. In doing so she highlights how the dominant narrative put forward by IGAD, and later IGAD Plus, claimed certain knowledge that had a profound effect on the design of transitional justice solutions. As Logo concludes:

conceptualizing the conflict as ethnic, and as one between two dominant tribes, meant that reports on the myriad of issues and roots of the conflict were left outside of the framework of the negotiations and outside of plausible solutions to the conflict, leaving significant gaps in how the international community conceptualized and intervened in the conflict.

These knowledge gaps are rendered more complex and have greater impact in the absence of meaningful transition: 'South Sudan as a complex, non-transition context, suffering from recurrent wars and cycles of human rights violations, is a difficult and risky environment for the production, use and dissemination of knowledge about human rights violations.' Given this, Logo underlines the 
importance of varied actors being able to contribute to knowledge production, and in particular the reports and recommendations made by civil society groups.

In the final chapter of Part III, Bigirimana renders visible and deconstructs the violence of communicative acts and narratives in the context of Burundi's transitional justice process. The chapter disassembles the complex, contradictory and contentious narrative landscape that shapes any peacebuilding and transitional justice debate in Burundi. In outlining first the challenges of producing academic work in and on this context, and his own intellectual journey that shaped and complicated this endeavour, his chapter speaks to the 'uneasy position of the academic' (Villumsen Berling and Bueger, 2015: 13). It goes further though in presenting the many fault lines of the narratives about the past that shape and define what, at specific points in time, is considered true and where these narratives diverge in their interpretations of the same events. The chapter not only asserts that the availability of cases perceived as similar or comparable (such as Rwanda for Burundi) can serve as narrative reference points and shape the narratives in a given context, but it also unpacks the politics and political use of labels such as 'ethnic conflict' and 'genocide'.

Through these diverse empirical and theoretical contributions, we lead to the conclusion of this book and its concrete contributions to the transitional justice and peacebuilding scholarships. As the concluding chapter discusses, the contributions outline (1) the different processes and actors which shape and constitute the politics of knowledge, (2) the ways in which norms and interpretations interact with power imbalances in the varied politics of knowledge landscapes, and (3) the research-policy-practice nexus as a particular facet of the politics of knowledge in the transitional justice and peacebuilding fields.

To conclude this introduction, it should be noted that the chapters we include are of course only part of the conversation that could, and should, be had on this subject. The case studies are all African countries, which is partly a result of the original case selection for the research project which has led to this book, and partly a function of the abstracts which were submitted through the open call process. In the spirit of self-reflexivity which imbued our project and which we hope imbues this book, it should also be noted that the process of writing and editing the contributions was itself an experience of grappling with the politics of knowledge production. As is always the case, but rarely openly discussed in the ensuing publications, the authors, reviewers and editors are not always of one mind. Indeed, the contentious nature of the book's subject matter, as well as the divisive empirical contexts represented, meant that we as editors were often in the difficult position of striking a delicate balance between supporting and controlling the knowledge product. Some of the issues about what should be included, which citations were required, and how events should be described were not in the end resolved. We believe this is not 
a weakness but is rather a strength of the book. We sought variety and inclusivity within the framework of the accepted academic vernacular and publication process. In the sense that the book is a knowledge product, it only captures a moment in time and thought in what are ongoing and open-ended debates. These debates go to the core of the way we understand the world around us and our effects within it. In this sense the book is as incomplete as the knowledge debates which underpin it.

\section{NOTES}

1. The idea of the double-bind was first developed for studies of schizophrenia.

2. Set of principles for the protection and promotion of human rights through action to combat impunity (E/CN.4/Sub.2/1997/20/Rev.1), 1997, accessed 14 April 2020 at https://digitallibrary.un.org/record/245520? $\ln =$ en

3. Accessed 14 April 2020 at https://www.ohchr.org/EN/Issues/TruthJusticeReparation /Pages/Index.aspx

4. The Protocol on Amendments to the Protocol on the Statute of the African Court of Justice and Human Rights (the 'Malabo Protocol') was adopted by the AU in June 2014 (AU, 2014). The envisaged African Court of Justice and Human Rights anticipates a General Affairs Section, a Human and Peoples' Rights Section and an International Criminal Law Section. Clarke et al. (2019: 1) assess that 'the merger of these three chambers addressing inter-state disputes, human rights and penal aspects into a single court with a common set of judges represents a significant development in Africa and in wider regional institution building and law making'.

5. See for example Lundy and McGovern (2008), Hinton (2010), McEvoy and McGregor (2008), Shaw et al. (2010), Sharp (2013, 2014, 2018), Wielenga (2018a, 2018b).

6. The project, 'Knowledge for Peace. Understanding Research, Policy, Practice Synergies', was funded by the Swiss National Science Foundation and the Swiss Development Cooperation. Active for four years from July 2016-July 2020 the project was undertaken by a team of researchers in Switzerland, South Sudan and Côte d'Ivoire with the case studies of Côte d'Ivoire, South Sudan and the African Union.

7. We would like to thank Brownen Webster for her research assistance in preparing notes for this chapter.

\section{REFERENCES}

African Commission for Human and Peoples' Rights (2019), 'Study on Transitional Justice and Human and Peoples' Rights in Africa', accessed 14 April 2020 at https:// www.achpr.org/news/viewdetail?id=185

Anders, G. and O. Zenker (2014), 'Transition and Justice: An Introduction', Development \& Change, 45 (3), 395-414.

Andrieu, K. (2010), 'Civilizing Peacebuilding: Transitional Justice, Civil Society and the Liberal Peace', Security Dialogue, 41 (5), 537-58.

Arthur, P. (2009), 'How “Transitions” Reshaped Human Rights. A Conceptual History of Transitional Justice', Human Rights Quarterly, 31 (2), 321-67. 
AU (2014), 'Protocol on Amendments to the Protocol on the Statute of the African Court of Justice and Human Rights', accessed 14 April 2020 at https://au.int/ en/treaties/protocol-amendments-protocol-statute-african-court-justice-and-human -rights

AU (2019), 'African Transitional Justice Policy', accessed 14 April 2020 at https://au .int/sites/default/files/documents/36541-doc-au_tj_policy_eng_web.pdf

Bell, C. (2009), 'Transitional Justice, Interdisciplinarity and the State of the "Field" or "Non-Field"', The International Journal of Transitional Justice, 3, 5-27.

Bennett, T., E. Brems, G. Corradi, L. Nijzink and M. Schotsmans (2012), African Perspectives on Tradition and Justice, Cambridge: Intersentia.

Bush, K. and C. Duggan (2014), 'How Can Research Contribute to Peacebuilding?', Peacebuilding, 2 (3), 303-21.

Carden, F. (2009), Knowledge to Policy: Making the Most of Development Research, London: IDRC SAGE.

Clarke, K. M., C. C. Jalloh and V. O. Nmehielle (2019), 'Introduction. Origins and Issues of the African Court of Justice and Human and People's Rights', in C. C. Jalloh, K. M. Clarke and V. O. Nmehielle (eds), The African Court of Justice and Human and People's Rights in Context. Development and Challenges, Cambridge and New York: Cambridge University Press, pp. 1-54.

Colvin, C. J. (2008), 'Purity and Planning: Shared Logics of Transitional Justice and Development', International Journal of Transitional Justice, 2 (3), 412-25.

Davies, H., S. Nutley and I. Walter (2005), 'Assessing the Impact of Social Science Research: Conceptual, Methodological and Practical Issues'. Background Paper for the Economic and Social Research Council Symposium on Assessing NonAcademic Impact of Research, May 2005, accessed 14 April 2020 at https://www .odi.org/sites/odi.org.uk/files/odi-assets/events-documents/4381.pdf

Hansen, T. O. (2014), 'The Vertical and Horizontal Expansion of Transitional Justice. Explanations and Implications for a Contested Field', in S. Buckley-Zistel, T. K. Beck, C. Braun and F. Mieth (eds), Transitional Justice Theories, Abingdon: Routledge, pp. 105-24.

Hinton, A. L. (2010), Transitional Justice. Global Mechanisms and Local Realities after Genocide and Mass Violence, New Brunswick, NJ: Rutgers University Press.

Kagoro, B. (2012), 'The Paradox of Alien Knowledge, Narrative and Praxis. Transitional Justice and the Politics of Agenda Setting in Africa', in M. C. Okello, C. Dolan, U. Whande, N. Mncwabe, L. Onegi and S. Oola (eds), Where Law Meets Reality. Forging African Transitional Justice, Cape Town, Dakar, Nairobi and Oxford: Pambazuka Press, pp. 4-52.

Krueger, A. K. (2016), 'The Global Diffusion of Truth Commissions: An Integrative Approach to Diffusion as a Process of Collective Learning', Theory and Society, 45 (2), 143-68.

Laws, S., C. Harper, N. Jones and R. Marcus (2013), Research for Development: A Practical Guide, London: SAGE.

Lundy, P. and M. McGovern (2008), 'Whose Justice? Rethinking Transitional Justice from the Bottom Up', Journal of Law and Society, 35 (2), 265-92.

Maddison, S. and L. J. Shepherd (2014), 'Peacebuilding and the Postcolonial Politics of Transitional Justice', Peacebuilding, 2 (3), 253-69.

McAuliffe, P. (2017), Transformative Transnational Justice and the Malleability of Post-Conflict States, Cheltenham, UK and Northampton, MA, USA: Edward Elgar Publishing. 
McEvoy, K. and L. McGregor (2008), Transitional Justice from Below. Grassroots Activism and the Struggle for Change, Oxford: Hart Publishing.

Miller, Z. (2008), 'Effects of Invisibility: In Search of the "Economic" in Transitional Justice', International Journal of Transitional Justice, 2 (3), 266-91.

Murphy, C. (2017), The Conceptual Foundations of Transitional Justice, Cambridge: Cambridge University Press.

Nagy, R. (2008), 'Transitional Justice as Global Project. Critical Reflections', Third World Quarterly, 29 (2), 275-89.

Ní Aoláin, F. D. and C. Campbell (2005), 'The Paradox of Transition in Conflicted Democracies', Human Rights Quarterly, 27 (1), 172-213.

Nouwen, S. M. H. (2014), "“As You Set out for Ithaka". Practical, Epistemological, Ethical, and Existential Questions about Socio-Legal Empirical Research in Conflict', Leiden Journal of International Law, 27 (1), 227-60.

Paris, R. (2011), 'Ordering the World: Academic Research and Policymaking on Fragile States', International Studies Review, 13 (1), 58-71.

Rubli, S. (2012), 'Transitional Justice. Justice by Bureaucratic Means?', swisspeace Working Paper, accessed 14 April 2020 at https:/www.files.ethz.ch/isn/154626/ WP4 2012.pdf

Sharp, $\bar{D}$. N. (2013), 'Interrogating the Peripheries. The Preoccupations of Fourth Generation Transitional Justice', Harvard Human Rights Journal, 26, 149-78.

Sharp, D. N. (2014), 'Addressing Dilemmas of the Global and the Local in Transitional Justice', Emory International Law Review, 29 (1), 71-117.

Sharp, D. N. (2018), Rethinking Transitional Justice for the Twenty-First Century. Beyond the End of History, New York: Cambridge University Press.

Shaw, R. and L. Waldorf (2010), 'Introduction. Localizing Transitional Justice', in R. Shaw, L. Waldorf and P. Hazan (eds), Localizing Transitional Justice. Interventions and Priorities after Mass Violence, Stanford, CA: University of Stanford Press, pp. 3-26.

Shaw, R., L. Waldorf and P. Hazan (2010), Localizing Transitional Justice. Interventions and Priorities after Mass Violence, Stanford, CA: University of Stanford Press.

Sikkink, K. (2011), The Justice Cascade. How Human Rights Prosecutions are Changing World Politics, New York: Norton.

Sriram, C. (2009), 'Transitional Justice and the Liberal Peace', in E. Newman, R. Paris and O. P. Richmond (eds), New Perspectives on Liberal Peacebuilding, Tokyo and New York: United Nations University Press, pp. 112-30.

Thomson, S. and R. Nagy (2011), 'Law, Power and Justice: What Legalism Fails to Address in the Functioning of Rwanda's Gacaca Courts', The International Journal of Transitional Justice, 5 (1), 11-30.

Verkoren, W. M. (2008), The Owl and the Dove: Knowledge Strategies to Improve Peacebuilding Practice of Local Non-Governmental Organisations, Amsterdam: University of Amsterdam Press.

Villumsen Berling, T. and C. Bueger (2015), 'Security Expertise: An Introduction', in T. Villumsen Berling and C. Bueger (eds), Security Expertise: Practice, Power, Responsibility, London and New York: Routledge, pp. 1-18.

Vinjamuri, L. and J. Snyder (2004), 'Advocacy and Scholarship in the Study of International War Crime Tribunals and Transitional Justice', Annual Review of Political Science, 7 (1), 345-62.

Wielenga, C. (2018a), 'What is "the Local"? Exploring Grassroots Justice Systems as a Means of Understanding the Local', Kujenga Amani, accessed 14 April 2020 
at https://kujenga-amani.ssrc.org/2018/04/17/what-is-the-local-exploring-grassroots -justice-systems-as-a-means-of-understanding-the-local/

Wielenga, C. (2018b), 'Justice on the Margins: Transitional, Tradition-Based and Transboundary Justice in Africa', Proceedings of the African Futures Conference, $2(1), 166-7$.

Yusuf, H. O. (2018), 'Colonialism and the Dilemmas of Transitional Justice in Nigeria', International Journal of Transitional Justice, 12 (2), 257-76.

Zunino, M. (2019), Justice Framed: A Genealogy of Transitional Justice, Cambridge: Cambridge University Press. 